\title{
Physicochemical of burdock (Arctium lappa L) tea depending on steaming and roasting treatment
}

\author{
$\mathrm{Yu}^{-\mathrm{Ri}} \mathrm{Kwon}^{1}$, Kwang-Sup Youn ${ }^{1,2 *}$ \\ ${ }^{1}$ Department of Food Science and Technology, Catholic University of Daegu, Gyeongsan 712-702, Korea \\ ${ }^{2}$ Institute of Food Science and Technology, Catholic University of Daegu, Gyeongsan 712-702, Korea
}

\section{증숙 및 볶음처리에 따른 우엉차의 품질특성}

\author{
권유리 ${ }^{1} \cdot$ 윤광섭 $1,2 *$ \\ ${ }^{1}$ 대구가톨릭대학교 식품공학전공, ${ }^{2}$ 대구가톨릭대학교 식품과학연구소
}

\begin{abstract}
To evaluate the processing adaptability of burdock (Arctium lappa $\mathbf{L}$ ) tea, the physicochemical properties of burdock tea treated with steaming and roasting were investigated. The tea treatments included hot-air drying after roasting (HDR, drying at $60^{\circ} \mathrm{C}$ for $6 \mathrm{hr}$ ), steaming after hot-air drying (SHD, steaming at $100^{\circ} \mathrm{C}$ for $10 \mathrm{~min}$ ), and steaming and then hot-air drying followed by roasting (SHDR, roasting at $250^{\circ} \mathrm{C}$ for $3 \mathrm{~min}$ ). The physicochemical properties, antioxidant activities, and sensory properties of the HDR, SHD, and SHDR teas were measured in hot water, and the tea was extracted from each sample. The color values of lightness (L) and yellowness (b) were lower in the HDR and SHDR teas, and the total sugar content of the SHDR tea was significantly higher than that of the other teas. The ABTS and DPPH radical scavenging abilities of the SHDR tea with a $500 \mathrm{mg} \%$ concentration were significantly higher than those of the SHD tea. In the sensory evaluation, the SHDR tea was ranked significantly higher than the other samples as to its color, flavor, taste, and overall acceptability. The results suggest that SHDR can be applied to burdock tea to achieve high quality and functionality.
\end{abstract}

Key words : burdock (Arctium lappa L), tea, sensory characteristics, antioxidant activities

\section{서 론}

최근 건강증진, 질병예방 및 치유 등에 기여하는 건강기 능성 식품에 대한 관심이 증대되면서 기능성 식품의 수요가 증가하고 있으며 이에 따른 다양한 기능성 식품개발을 위한 연구도 경쟁적으로 진행되고 있다(1). 그 중 건강 음용차에 대한 대중의 관심 증가로 다양한 식물체를 침출차로 개발하 고자 하는 연구가 수행되고 있으며, 침출차의 품질향상을 위해 맛과 풍미와 기능성을 높이고자하는 가공기술의 개발 이 진행되고 있다.

우엉(Arctium lappa L.)은 국화과에 속하는 식물로서 원 산지는 유럽 및 아시아의 온난 지역으로 알려져 있으며 우리나라에서는 주로 경상남도 지역에서 널리 재배되고

*Corresponding author. E-mail : ksyoun@cu.ac.kr

Phone : 82-53-850-3209, Fax : 82-53-850-3209
있다(2). 우엉은 당질이 주성분인 알칼리성 식품으로 특유 의 향기와 약리효과가 있으며 섬유질이 많고 비타민 함량이 적은 것으로 알려져 있다(3). 당질의 대부분은 inulin의 형태 로 존재하고, Trp P-1(3-amino-1,4-dimethyl-5H-pyrido\{4,3$b$ jindole) 등 돌연변이원이 되는 여러 가지 아미노산 열분해 산물을 불활성화 시키는 역할을 하며, 이러한 작용은 우엉 에 존재하는 열에 강한 lignin 유사물질로 알려져 있다(4) 또한 우엉에는 항산화성을 가지는 phenol 성분인 caffeoylquinic acid 유도체가 존재하는 것으로 알려져 있으며(5), 고혈압, 통풍, 심혈관계 질환, 간염 등에 효과가 있어 항변이원성, 항암, 항노화 등 다양한 기능성을 가지고 있는 것으로 보고 되고 있다(6). 우엉을 이용한 연구로는 주로 우엉뿌리 추출 물이 ICAM-1(intracellular adheision molecule-1)과 NO (Nitric oxide)조절에 미치는 항염증 효과(7), 우엉뿌리 polyphenol oxidase의 부분정제 및 특성(8), 우엉을 첨가한 설기떡의 품질특성(9), 가공온도 및 갈변 억제제가 신선절 
단 우엉의 품질특성에 미치는 영향(10) 등이 보고되고 있다.

이처럼 우엉의 다양한 기능에도 불구하고 특유의 떫은맛 으로 인해 가공제품의 개발이 제한됨에 따라 떫은맛을 개선 시킬 수 있는 가공기술의 개발이 필요하다. 우엉의 떫은 맛은 가용성 탄닌에 의한 현상으로 혀의 단백질을 응고시켜 수렴작용을 하기 때문으로 기호성에 영향을 미친다. 또한 산화, 환원반응의 기질로 작용하여 식품의 색상에 영향을 미치며 단백질과 소수성 결합 및 수소결합을 통해 식품 내에 함유된 단백질의 정상적인 이용을 방해하는 것으로 알려져 있다(11). 이러한 떫은 맛을 제거하기 위한 방법으로 는 열처리 방법이 있으며(12), 이는 단순히 떫은 맛을 제거 할 뿐만 아니라 식품에 향과 맛을 부여하는 장점을 가진다. 열처리에는 다양한 방법이 있으며, 그 중 증숙 공정은 증기 를 이용해 열처리를 하여 세포의 구성성분들의 변화를 유도 하여 새로운 화합물을 만들어 내거나 세포 조직을 파괴하여 유용성분 용출을 극대화하는 공정으로 주로 인삼 가공에서 많이 사용된다(13). 또한 볶음 공정은 짧은 시간에 높은 온도로 처리하여 갈변반응을 촉진시키므로 데치기나 스팀 처리와는 달리 독특한 향미가 형성되어 기호성을 높일 수 있는 방법이다(14). 또한 볶음처리를 통하여 식물체 중의 환원당과 질소화합물이 갈색화 반응을 일으켜 갈색색소와 구수한 향미물질을 생성하며, 이때 생성된 Maillard 반응 생성물들은 항산화성, 항돌연변이원성 등 여러 가지 생리 활성을 나타내는 것으로 밝혀지고 있다(15).

따라서 본 연구에서는 우엉의 가공적 활용성 증대를 위 한 목적으로 우엉차를 제조를 실시하였으며 증숙 및 볶음 처리에 따른 이화학적 특성, 항산화 활성 및 관능적 평가를 비교분석하여 우엉차의 제품화를 위한 기초자료를 제시하 고자 한다.

\section{재료 및 방법}

재 료

본 실험에 사용된 우엉은 경북 경산시내에서 2012년 5월 에 구입하여 사용하였으며, 수세하여 이물질을 제거 및 박 피 후 $4 \mathrm{~mm}$ 의 크기로 절단하여 사용하였다. 실험에 사용된 모든 시약은 Sigma-Aldrich사(St. Louis, MO, USA)의 제품 을 사용하였다.

\section{증숙 및 볶음 처리에 따른 우엉차 제조}

우엉차를 제조하기 위해 슬라이스한 우엉 $300 \mathrm{~g}$ 을 가정 용 스팀솥(Chefline, Bucheon, Korea)를 이용하여 10 분간 증숙처리를 실시하였다. 그 후 우엉을 hot air dryer (OF-22GW, Jeiotec., Daejeon, Korea)를 이용하여 $60^{\circ} \mathrm{C}$ 에서 6시간 건조하였다. 건조된 우엉은 볶음기(JIS-E10, Jeil Co., Ltd., Seoul, Korea)를 이용하여 $250^{\circ} \mathrm{C}$ 에서 3 분간 볶음처리
를 하였다. 볶음이 완료되면 즉시 실온에서 냉각시켰으며 이때 시료는 $30 \pm 2 \mathrm{~g}$ 의 건조중량을 나타내었다. 건조된 우엉 은 각 조건별로 나누어 polyethylene bag에 밀봉포장하여 $4{ }^{\circ} \mathrm{C}$ 에서 냉장 보관하면서 분석에 사용하였다. 상기의 조건 에 따라 건조 후 볶음처리는 $\mathrm{HDR}$, 증숙 후 건조처리는 $\mathrm{SHD}$, 증숙 후 건조하여 볶음처리는 SHDR로 분류하여 실 험에 사용하였다.

\section{시료 침출액의 제조}

우엉차의 품질특성 및 항산화능 분석을 위해 건조 처리 한 우엉 $1 \mathrm{~g}$ 에 증류수 $100 \mathrm{~mL}$ 를 가하여 $80^{\circ} \mathrm{C}$ 에서 3 분간 우려낸 다음 Whatman No. 1 여과지로 여과한 여액을 시료 로 사용하였다. 침출 조건은 예비실험을 통하여 관능평가 를 기준으로 차로 음용하기에 적합한 시간을 선정하였다.

\section{색도, $\mathrm{pH}$ 및 탁도}

색도는 색차계(Chromameter CR-200, Minolta, Tokyo, Japan)로 측정하였으며, 밝기를 나타내는 L(lightness), 적색 도를 나타내는 $\mathrm{a}$ (redness), 황색도를 나타내는 b(yellowness) 를 측정하였다. $\mathrm{pH}$ 는 침출 시료를 취하여 $\mathrm{pH}$ meter(Toledo $\mathrm{Gmbh} \mathrm{HG} 53$, Greifensee, Switzerland)로 측정하였으며, 탁 도는 spectrophotometer(UV1601, Shimadzu, Kyoto, Japan) 를 사용하여 $675 \mathrm{~nm}$ 에서 흡광도를 측정하였다.

\section{총당 함량}

총당 함량은 phenol-sulfate acid법(16)에 따라 측정하였 다. 즉 침출액 $1 \mathrm{~mL}$ 에 $5 \%$ phenol $1 \mathrm{~mL}$ 와 sulfuric acid 5 $\mathrm{mL}$ 를 가하여 발색시킨 다음 20 분간 방치 후 spectrophotometer 를 이용하여 $470 \mathrm{~nm}$ 에서 흡광도를 측정하였다. 총당의 정 량은 glucose 표준품을 사용하여 검량선을 작성하여 실시하 였다.

\section{총 폴리페놀 및 플라보노이드 함량}

폴리페놀 함량은 Dewanto 등(17)의 방법에 따라 침출물 $100 \mu \mathrm{L}$ 에 $2 \%$ sodium carbonate $2 \mathrm{~mL}$ 과 $50 \%$ Folin-Ciacalteu reagent $100 \mu \mathrm{L}$ 을 가한 후 $720 \mathrm{~nm}$ 에서 흡광도를 측정하였으 며 gallic acid(Sigma-Aldrich Co., USA)의 검량선에 의하여 함량을 산출하였다. 총 플라보노이드 함량은 Saleh와 Hameed(18)의 방법에 따라 침출물 $100 \mathrm{~mL}$ 에 $5 \%$ sodium nitrite $0.15 \mathrm{~mL}$ 을 가한 후 $25^{\circ} \mathrm{C}$ 에서 6 분간 방치한 다음 $10 \%$ aluminium choloride $0.3 \mathrm{~mL}$ 를 가하여 $25^{\circ} \mathrm{C}$ 에서 5 분간 방치 하였다. 다음 $1 \mathrm{~N} \mathrm{NaOH} 1 \mathrm{~mL}$ 를 가하고 vortex상에서 가한 후 $510 \mathrm{~nm}$ 에서 흡광도를 측정하였으며 rutin hydrate (Sigma-Aldrich Co.)의 검량선에 의하여 함량을 산출하였 다. 


\section{$\mathrm{DPPH}$ 라디칼 소거활성}

Blois(19)의 방법에 따라 침출물 $0.2 \mathrm{~mL}$ 에 $0.4 \mathrm{mM} \mathrm{DPPH}$ (1,1-diphenyl-2-picryl- hydrazyl)용액 $0.8 \mathrm{~mL}$ 를 가하여 10 분 간 방치 한 다음 $525 \mathrm{~nm}$ 에서 흡광도를 측정하였으며 계산 식, electron donating ability $(\%)=100-[(\mathrm{OD}$ of sample/OD of control $\times 100$ ]에 의하여 활성도를 산출하였다.

\section{$\mathrm{ABTS}+$ 라디칼 소거활성}

$\operatorname{Re}$ 등(20)의 방법에 따라 $7.4 \mathrm{mM}$ ABTS 2,2'-azino-bis(3ethylbenzothiazoline-6-sulfonic acid) 와 $2.6 \mathrm{mM}$ potassium persulfate를 혼합하여 실온 - 암소에서 24시간 동안 방치하 여 radical을 형성시킨 다음 실험 직전에 ABTS 용액을 732 $\mathrm{nm}$ 에서 흡광도가 $0.700 \pm 0.030$ 이 되도록 phosphate buffer saline(PBS, pH 7.4)로 희석하여 사용하였다. 희석된 용액 $950 \mu \mathrm{L}$ 에 침출물 $50 \mu \mathrm{L}$ 를 가하여 암소에서 10 분간 반응시 킨 후 $732 \mathrm{~nm}$ 에서 흡광도를 측정하였으며 계산식, ABTS radical scavenging ability $(\%)=100-[(\mathrm{OD}$ of sample/OD of control $\times 100]$ 에 의하여 활성을 산출하였다.

\section{환원력}

Saeedeh와 Asan(21)의 방법에 따라 침출물 $1 \mathrm{~mL}$ 에 0.2 $\mathrm{M}$ phosphate buffer(pH 6.6) $2.5 \mathrm{~mL}$ 와 $1 \%$ potassiumm ferricyanide 용액 $2.5 \mathrm{~mL}$ 를 가한 후 $50^{\circ} \mathrm{C}$ 에서 30 분간 반응시 켰다. 다음에 $10 \%$ trichloroacetic acid(TCA) 용액 $2.5 \mathrm{~mL}$ 를 가한 후 $1,650 \times \mathrm{g}$ 에서 10 분간 원심분리 하였으며, 상징액 $2.5 \mathrm{~mL}$ 에 증류수 $2.5 \mathrm{~mL}$ 와 $0.1 \% \mathrm{FeCl}_{3}$ 용액 $0.5 \mathrm{~mL}$ 를 가한 후 $700 \mathrm{~nm}$ 에서 흡광도를 측정하였다.

\section{관능평가}

우엉차의 관능적 품질을 평가하기 위하여 관능검사를 실시하였다. 관능적 품질 평가는 과립에서 중요한 품질지 표가 될 수 있는 색, 맛, 냄새 및 종합적인 기호도를 5점 채점법에 따라 평가하였으며 조사 패널은 식품가공학을 전공하는 대학원생 및 학부생 15 명을 대상으로 조사하였 다. 관능검사의 조건은 예비실험을 통하여 조건을 확립하 였으며 시료 $1 \mathrm{~g}$ 에 끓인 물을 $70^{\circ} \mathrm{C}$ 로 식힌 후 일회용 종이컵 에 $100 \mathrm{~mL}$ 를 가하여 3 분간 침출한 액을 이용하여 관능검사 를 실시하였다.

\section{통계처리}

모든 실험은 3회 반복으로 행하여 평균치와 표준편차로 나타내었고, 유의성 검증은 version 12의 SPSS(Statistical Package for Social Science, SPSS Inc., Chicago, IL, USA) software package program을 이용하여 Duncan's multiple range test를 행하였다.

\section{결과 및 고찰}

우엉차의 $\mathrm{pH}$, 탁도 및 총당 함량

다양한 열처리 방법에 따른 우엉차의 $\mathrm{pH}$, 탁도 및 총당을 측정한 결과는 Table 1 과 같다. $\mathrm{pH}$ 의 경우 증숙처리 후 건조한 우엉차(SHD), 증숙 후 건조하여 볶은 우엉차 (SHDR), 건조 후 볶음처리 한 우엉차(HDR)의 순으로 나타 났으나, 수치적으로 큰 차이를 나타내지 않았다. 탁도의 경우 증숙처리 후 건조한 우엉차(SHD)가 2.17로 가장 높은 값을 나타내었으며 건조 후 볶음 처리한 우엉차(HDR)은 0.70 으로 낮아지는 경향을 보였다. 우엉차의 총당 함량은 $\mathrm{SHDR}$ 에서 가장 높았으며 $\mathrm{HDR}>\mathrm{SHD}$ 의 순으로 나타났다. $\mathrm{Bae}$ 등(22)은 로스팅 조건에 따른 맥문동의 총당을 측정한 결과, 로스팅 처리한 맥문동에서 총당이 증가되는 경향을 확인하였으며 본 실험의 결과와 일치하였다. 이러한 결과 는 당질의 열수 추출수율을 결정하는 요인인 볶음처리에 따른 수용성 당질 함량과 조직구조의 변화에 기인한 것으로 사료된다(23).

Table 1. $\mathrm{pH}$, turbidity and total sugar contents of burdock tea treated by steaming, drying, roasting methods

\begin{tabular}{cccc}
\hline $\begin{array}{c}\text { Processing } \\
\text { conditions }\end{array}$ & $\mathrm{pH}$ & Turbidity (NTU) & $\begin{array}{c}\text { Total sugar } \\
\text { contents }\end{array}$ \\
\hline HDR & $5.69 \pm 0.01^{2)(3)}$ & $0.70 \pm 0.17^{\mathrm{c}}$ & $93.13 \pm 0.29^{\mathrm{b}}$ \\
SHD & $5.94 \pm 0.01^{\mathrm{a}}$ & $2.17 \pm 0.12^{\mathrm{a}}$ & $75.43 \pm 0.80^{\mathrm{c}}$ \\
SHDR & $5.75 \pm 0.01^{\mathrm{b}}$ & $1.13 \pm 0.15^{\mathrm{b}}$ & $138.47 \pm 0.69^{\mathrm{a}}$ \\
\hline
\end{tabular}

${ }^{1)}$ Abbreviation: HDR; Hot air drying and roasting, SHD; Steaming and hot air drying, SHDR; steaming and hot air drying and roasting

${ }^{2)}$ Values are means \pm standard deviations of triplicate determinations

${ }^{3)}$ Different superscripts within a column $(\mathrm{a}-\mathrm{c})$ indicate significant differences $(\mathrm{p}<0.05)$.

\section{우엉차의 색도}

증숙 및 볶음처리에 따라 제조한 우엉차의 색도를 측정 한 결과는 Table 2 와 같다. 밝기는 증숙 처리 후 건조한 우엉차(SHD)가 높은 값을 나타내었으며 증숙 처리 후 건조 하여 볶음 처리한 우엉차(SHDR)는 가장 낮았다. 또한 증숙 처리 후 건조한 우엉차(SHD)의 경우 적색도는 증가하고

Table 2. Color of burdock tea treated by steaming, drying, roasting methods

\begin{tabular}{cccc}
\hline \multirow{2}{*}{$\begin{array}{c}\text { Processing } \\
\text { conditions }\end{array}$} & \multicolumn{3}{c}{ Color } \\
\cline { 2 - 4 } & Lightness (L) & Redness (a) & Yellowness (b) \\
\hline HDR & $61.36 \pm 1.10^{2) b 3)}$ & $-1.06 \pm 0.04^{\mathrm{c}}$ & $9.25 \pm 0.18^{\mathrm{a}}$ \\
SHD & $64.35 \pm 0.67^{\mathrm{a}}$ & $1.03 \pm 0.04^{\mathrm{a}}$ & $-2.65 \pm 0.04^{\mathrm{c}}$ \\
SHDR & $57.36 \pm 1.31^{\mathrm{c}}$ & $-0.69 \pm 0.06^{\mathrm{b}}$ & $5.58 \pm 0.12^{\mathrm{b}}$ \\
\hline
\end{tabular}

${ }^{1)}$ Abbreviation: HDR; Hot air drying and roasting, SHD; Steaming and hot air drying, SHDR; steaming and hot air drying and roasting

${ }^{2)}$ Values are means \pm standard deviations of triplicate determinations

${ }^{3)}$ Different superscripts within a column $(\mathrm{a}-\mathrm{c})$ indicate significant differences $(\mathrm{p}<0.05)$. 
황색도는 감소하였으며, 건조 후 볶음처리한 우엉차(HDR) 는 가장 낮은 적색도와 높은 황색도를 나타내어 Lee 등(24) 의 결과와 일치하는 경향을 보였다. 전체적으로 볶음처리 후에 명도는 낮아지고 황색도는 증가하는 경향을 나타내었 는데, 이는 우엉차 제조 시 열에 의해 시료 자체 내에 당성분 과 기타 성분과의 화학적 반응으로 갈색화가 일어나 황색도 가 많이 증가되는 것으로 판단된다. 또한 증숙처리를 하지 않은 $\mathrm{HDR}$ 의 경우 증숙처리한 $\mathrm{SHD}$ 와 $\mathrm{SHDR}$ 에 비해 낮은 적색도와 높은 황색도를 나타내었는데, 이는 증숙처리 시 우엉의 효소적 및 비효소적 갈변을 억제시켜 가공방법에 따라 갈변되는 정도의 차이로 사료되며 적절한 증숙 및 볶음처리는 우엉차의 색상에 영향을 미치는 것으로 생각된 다.

\section{우엉차의 총 폴리페놀 및 플라보노이드 함량}

페놀성 화합물은 식물계에 널리 분포되어 물질로 다양한 구조와 분자량을 가지며 페놀성 화합물의 phenol hydroxyl 기를 통해 항산화, 항암 및 항균 등의 생리기능을 가지는 것으로 알려져 있다(25). 다양한 방법으로 처리한 우엉차의 총 폴리페놀 함량 및 플라보노이드 함량을 측정한 결과는 Table 3와 같다. 볶음처리에 따라 폴리페놀 및 플라보노이 드 함량이 높아지는 경향을 나타내었는데, 이는 Hong 등 (26)과 Lee 등(1)의 연구 결과와 같은 경향을 보였으며, 볶음 공정에 따른 가열처리에 의해 우엉의 내부 조직의 파괴로 인하여 페놀성 화합물이 쉽게 추출되어 함량이 증가하는 것으로 판단된다. 또한 Lee(24)의 보고에 따르면 열풍건조 후 볶음처리한 씀바귀의 총 폴리페놀물질의 함량이 63.49 $\mathrm{mg} / 100 \mathrm{~mL}$ 로 가장 높았다고 보고하여 본 연구와 일치하였 다. 총 플라보노이드 함량의 경우 증숙처리한 $\mathrm{SHD}$ 와 증숙 후 볶음처리한 SHDR에서 각각 $2.07 \mathrm{mg} / \mathrm{g}, 2.21 \mathrm{mg} / \mathrm{g}$ 으로 높은 함량을 보였으며 건조 후 볶음처리한 $\mathrm{HDR}$ 에서는 1.63 $\mathrm{mg} / \mathrm{g}$ 으로 낮은 값을 나타내었다. 이는 총 폴리페놀 함량과 상반되는 경향을 나타내었으며 증숙처리한 구간에서 높은 함량을 나타내는 것을 알 수 있었다. 이는 증숙과정을 통해 용해도가 낮은 플라보노이드계 화합물이 쉽게 용해되었을

Table 3. Total polyphenol contents and total flavonoids contents of burdock tea treated by steaming, drying, roasting methods

\begin{tabular}{ccc}
\hline $\begin{array}{c}\text { Processing } \\
\text { conditions }\end{array}$ & $\begin{array}{c}\text { Polyphenols } \\
\left(\mathrm{mg} \mathrm{GAE}^{2} / \mathrm{g}\right)\end{array}$ & $\begin{array}{c}\text { Flavonoids } \\
\left(\mathrm{mg} \mathrm{RHE}^{3} / \mathrm{g}\right)\end{array}$ \\
\hline HDR & $6.89 \pm 0.13^{4) 25}$ & $1.63 \pm 0.03^{\mathrm{b}}$ \\
$\mathrm{SHD}$ & $4.83 \pm 0.20^{\mathrm{c}}$ & $2.07 \pm 0.15^{\mathrm{a}}$ \\
$\mathrm{SHDR}$ & $6.19 \pm 0.14^{\mathrm{b}}$ & $2.21 \pm 0.26^{\mathrm{a}}$ \\
\hline
\end{tabular}

${ }^{1)}$ Abbreviation: HDR; Hot air drying and roasting, SHD; Steaming and hot air drying, SHDR; steaming and hot air drying and roasting

${ }^{2-3) /} \mathrm{GAE}$, galic acid equivalents; RHE, rutin hydrate equivalents

${ }^{4)}$ Values are means \pm standard deviations of triplicate determinations

${ }^{5}$ Different superscripts within a column $(a-c)$ indicate significant differences $(\mathrm{p}<0.05)$.
것으로 판단된다(23).

\section{우엉차의 항산화 효능}

증숙 및 볶음처리에 따라 제조한 우엉차의 항산화 효능 을 측정한 결과는 Table 4 와 같다. 시료의 특성에 따라 $\mathrm{DPPH}$ 라디칼과 $\mathrm{ABTS}$ 라디칼과의 결합 정도가 다를 수 있어(27), 본 연구에서는 DPPH 및 $\mathrm{ABTS}$ 라디칼 소거능과 환원력을 모두 분석하였다. ABTS 라디칼 소거능의 경우 볶음 처리를 한 구간이 증숙처리한 구간보다 높은 활성을 보였으며, 특히 증숙 후 볶음처리한 우엉차에서 $85.66 \%$ 로 높은 활성을 나타내었다. 한편, DPPH 라디칼 소거능은 항 산화력을 나타내는 지표로 사용하며 일반적으로 페놀성 물질의 함량과 연관성이 아주 높은 것으로 알려져 있다(26) $\mathrm{DPPH}$ 라디칼 소거능을 측정한 결과 또한 볶음 처리를 한 구간에서 높은 활성을 나타내었다. Kim 등(27)과 Chio 등 (28)은 각각 검정콩과 여주의 볶음 처리 후 항산화 효과가 증가한다고 보고하였으며 이는 본 연구의 결과와 일치하였 다. 환원력의 경우 볶음 처리를 한 구간에서 높은 활성을 보였으며, 전체적으로 증숙 후 건조하여 볶음처리한 우엉 차의 항산화 활성이 가장 높은 것으로 나타났다. 이러한 결과는 앞선 총 페놀함량과 라디칼 소거능의 측정 결과처럼 열처리가 매우 유사한 결과를 보이고 있음을 확인하였으 며, 이는 대표적인 항산화 성분인 폴리페놀 및 플라보노이 드 등의 페놀성 화합물이 볶음 처리에 의해 증가하여 항산 화 효과가 증가되었을 것으로 사료된다(29). 한편, 양성 대 조군으로 합성 산화방지제인 BHT(butylated hydroxytoluene, $95.38 \%$ )보다는 농도대비하여 현저히 낮은 활성을 나타내었으나 이러한 가공방법이 고품질 제품의 생산에 기여할 수 있을 것으로 사료된다.

Table 4. ABTS and DPPH radical scavenging ability (RSA), reducing power of burdock root tea treated by steaming, drying, roasting methods

\begin{tabular}{cccc}
\hline Measurement ${ }^{1)}$ & $\begin{array}{c}\text { ABTS radical } \\
\text { scavenging ability } \\
(\%)\end{array}$ & $\begin{array}{c}\text { DPPH radical } \\
\text { scavenging ability } \\
(\%)\end{array}$ & $\begin{array}{c}\text { Reducing power } \\
\left(\mathrm{OD}_{700}\right)\end{array}$ \\
\hline HDR & $75.13 \pm 1.96^{2 \mathrm{bb3})}$ & $81.88 \pm 0.47^{\mathrm{b}}$ & $0.61 \pm 0.02^{\mathrm{b}}$ \\
SHD & $62.10 \pm 1.10^{\mathrm{c}}$ & $65.25 \pm 0.92^{\mathrm{c}}$ & $0.49 \pm 0.02^{\mathrm{c}}$ \\
SHDR & $85.66 \pm 2.77^{\mathrm{a}}$ & $92.11 \pm 1.46^{\mathrm{a}}$ & $0.76 \pm 0.02^{\mathrm{a}}$ \\
$\begin{array}{c}\text { Positive control, } \\
\text { BHT }\end{array}$ & $97.46 \pm 1.20$ & $94.25 \pm 0.35$ & $0.99 \pm 0.07$ \\
\hline
\end{tabular}

${ }^{11}$ The concentration of positive control (BHT : butylated hydroxytoluene) solutions were measured at $50 \mathrm{mg} \%$, and all test sample were measured at $500 \mathrm{mg} \%$

${ }^{2)}$ Values are means \pm standard deviation of triplicate determinations

${ }^{3}$ Different superscripts within a column $(\mathrm{a}-\mathrm{c})$ indicate significant differences $(\mathrm{p}<0.05)$.

\section{우엉차의 관능평가}

우엉의 다양한 가공적 활용성을 위하여 증숙 및 볶음처 리에 따라 제조한 우엉차의 색, 향, 단맛, 떫은맛, 구수한 
Table 5. sensory properties of burdock root tea treated by steaming, drying, roasting methods

\begin{tabular}{ccccccc}
\hline Processing conditions & Color & Flavor & Sweet taste & Astringent taste & Roasted taste & Overall acceptance \\
\hline HDR & $4.33 \pm 0.82^{2) \mathrm{a} 3)}$ & $4.00 \pm 0.89^{\mathrm{a}}$ & $3.67 \pm 0.82^{\mathrm{a}}$ & $2.50 \pm 0.55^{\mathrm{a}}$ & $3.92 \pm 0.58^{\mathrm{b}}$ & $4.00 \pm 0.63^{\mathrm{a}}$ \\
SHD & $2.33 \pm 1.03^{2) \mathrm{b}}$ & $2.00 \pm 0.63^{\mathrm{b}}$ & $1.50 \pm 0.55^{\mathrm{b}}$ & $2.17 \pm 0.75^{\mathrm{a}}$ & $1.67 \pm 0.52^{\mathrm{c}}$ & $1.83 \pm 0.75^{\mathrm{b}}$ \\
SHDR & $4.50 \pm 0.84^{2) \mathrm{a}}$ & $4.17 \pm 0.75^{\mathrm{a}}$ & $4.00 \pm 1.10^{\mathrm{a}}$ & $2.83 \pm 0.75^{\mathrm{a}}$ & $4.67 \pm 0.52^{\mathrm{a}}$ & $4.50 \pm 0.55^{\mathrm{a}}$ \\
\hline
\end{tabular}

${ }^{11}$ Abbreviation: HDR; Hot air drying and roasting, SHD; Steaming and hot air drying, SHDR; steaming and hot air drying and roasting

${ }^{2)}$ Values are means \pm standard deviations of triplicate determinations

${ }^{3}$ Different superscripts within a column $(\mathrm{a}-\mathrm{c})$ indicate significant differences $(\mathrm{p}<0.05)$

맛 그리고 종합적 기호도에 대한 관능평가를 실시한 결과는 Table 5 와 같다. 색과 향에 대한 기호도의 경우 볶음처리를 한 HDR과 SHDR에서 4점 이상의 우수한 기호도를 나타내 었으며, 증숙 후 건조한 $\mathrm{SHD}$ 의 경우 낮은 기호도를 나타내 었다. 단맛과 떫은맛, 구수한 맛의 기호도 역시 볶음처리한 우엉차가 가장 높게 평가되었으며, 특히 증숙 및 볶음처리 한 SHDR의 기호도가 가장 높았다. 전반적인 기호도의 경우 도 볶음처리한 우엉차에서 높게 나타났으며 증숙 후 건조한 우엉차에 비해 볶음처리를 할 경우 종합적인 기호도가 크게 증가하였다. 이러한 결과는 열처리에 의해 구수한 향을 나 타냄으로서 향에 대한 기호도가 우수해지고 동시에 유리당 및 기타성분의 용출이 쉬워짐에 따라 관능평가 시 쓴맛에 대한 감지도가 낮게 나타나 기호도가 높아진 것으로 생각된 다. 볶음 처리에 의해 가열 과정 중에 일어나는 갈색화 반응 생성물은 식품의 독특한 향미를 부여하여 향, 맛에 대한 기호도가 증가하여 종합적인 기호도도 증가한 것으로 사료 되며(1), 이는 볶음 처리에 따라 관능적 품질 특성이 향상되 는 Lee 등(24)과 Kwak(30)의 보고와 일치하는 경향을 나타 내었다.

\section{요 약}

본 연구에서는 우엉의 활용성 증진을 위하여 우엉차를 제조하였으며 기호성과 기능성 증진을 위하여 증숙 및 볶음 처리에 따른 우엉차의 품질특성 및 항산화 활성을 검토하였 다. 색도는 증숙처리하여 건조한 우엉차(SHD)보다는 건조 후 볶음 처리를 한 $\mathrm{HDR}$ 과 증숙 후 건조하여 볶음처리한 SHDR에서 높은 황색도를 나타냈다. $\mathrm{pH}$ 는 시료 간의 유의 적인 차이는 없었으나 탁도에서는 증숙처리 후 건조한 우엉 차에서 높은 값을 나타내었으며, 총당의 경우 볶음 처리 시 비교적 높은 함량을 보였다. 우엉차의 항산화 활성을 평가하기위해 $\mathrm{ABTS}$ 및 $\mathrm{DPPH}$ 라디칼 소거능과 환원력을 실시하였으며, 전체적으로 볶음 처리를 하였을 때 활성이 높아지는 경향을 보여 증숙 처리보다는 볶음처리에서 우수 한 것으로 나타났다. 또한 우엉차의 관능적 특성으로는 색, 향, 단맛, 떫은 맛, 구수한 맛 및 종합적 기호도를 평가하였 으며 증숙처리 후 건조한 구간보다 볶음처리 시 떫은맛이
감소되고 단맛, 구수한 맛이 향상되었고, 풍미, 색상 및 종합 적 기호도가 향상되었다. 이러한 결과를 종합하여 볼 때 우엉차 제조 시 열처리는 기능성 및 기호도가 증진시켜 품질의 향상에 영향을 주며 증숙과 볶음 공정을 적절히 적용하여 제조하는 것이 효과적인 것으로 생각된다.

\section{References}

1. Lee SH, Lee YR, Hwang IG, Woo KS, Kim KH, Kim KJ, Jeong HS (2009) Antioxidant activities and quality characteristics of germinated rough rice tea according to roasting temperature, time and leaching condition. Korean J Food Sci Technol, 41, 386-391

2. Jeong SB, Shin MS (1990) The oriental medicinal dictionary Younglimsa, Seoul, Korea, p 1010-1011

3. Lee JH, Lim JH, Cheung JD, Suh DW (2003) Major characteristics of Burdock (Arctium lappa L.) native to Yeong-Nam region. Korean J Plant Res, 16, 8-14

4. Shinohara K, Kuroki S, Kong ZL and Hosoda H (1988) Antimutagenicity of dialyzates of vegetables and fruits. Agric Biol Chem, 52, 1369-1375

5. Maruta Y, Kawabata J, Niki R (1995) Antioxidative caffeoylquinic acid derivatives in the root of burdock (Arctium lappa L.). J Agric Food Chem, 43, 2592-2595

6. Lin CC, Lin JM, Yang JJ, Chuang SC, Ujiie T (1996) Antinflammatory and radical scavenging effect of Arctium lappa. Am J Chinese Med, 24, 127-137

7. Kim YJ, Kang SC, Namkoong S, Choung MG, Shon EH (2012) Anti-inflammatory effects by Arctium lappa L. root extracts through the regulation of ICAM-1 and nitric oxide. Korean J Plant Res, 25, 1-6

8. Lim JH, Jeong MC, Moon KD (2005) Purification and characterization of polyphenol oxidase from Burdock (Arctium lappa L.). Korean J Food 12, 489-495

9. Park BG (2009) Quality characteristics of Sulgidduck by the addition for burdock. Sejong University, Seoul, Korea, p 1-3 
10. Chung HS, Seong JH, Moon KD (2012) Effects of processing temperature and browning inhibitor on quality properties of fresh-cut burdock roots. Korean J Food Preserv, 19, 31-36

11. Lee SC, Kim SY, Choi IS, Jung, MY, Yang SM, Chae HJ (2010) Effect of soaking and heat treatment conditions on physicochemical and organoleptic quality of lotus root. Korean J Food Sci Technol, 42, 45-49

12. Kim NM, Kim DH (2000) Quality change of cinnamon extract prepared various drying methods. Korean J Food Nutr, 13, 152-157

13. Song CH, Seo YC, Choi WY, Lee CG, Kim DU, Chung JY, Chung HC, Park DS, Ma CJ, Lee HY (2012) Enhancement of antioxidative activity of Codonopsis lanceolata by stepwise steaming process. Korean J Med Crop Sci, 20, 238-244

14. Park MH, Sohn HJ, Joeon BS, Kim NM, Park CK, Kim AK, Kim KC (1999) Studies on flavor components and organoleptic properties in roasted red ginseng marc. $\mathbf{J}$ Ginseng Res, 23, 211-216

15. Jung HJ, Lee SR (1991) Browning and mutagenicity of roasted barley and sesame seeds. Korean J Food Sci, 23, 280-285

16. Saha SK, Brewer CF (1994) Determination of the concentrations of oligosaccharides, complex type carbohydrates, and glyco-proteins using the phenol-sulfuric acid method. Carbohyd Res, 254, 157-167

17. Dewanto V, Wu X, Adom KK, Liu RH (2002) Thermal processing enhances the nutritional value of tomatoes by increasing total antioxidant activity. J Agric Food Chem, 50, 3010-3014

18. Saleh ES, Hameed A (2008) Total phenolic contents and free radical scavenging activity of certain Egyptian Ficus species leaf samples. Food Chem, 114, 1271-1277

19. Blois MS (1958) Antioxidant determination by the use of a stable free radical. Nature, 26, 1199-1200

20. Re R, Pellegrini N, Proteggente A, Pannala A, Yang M, Rice-Evans C (1999) Antioxidant activity applying an improved ABTS radial cation decolorization assay. Free Radic Biol Med, 26, 1231-1237
21. Saeedeh AD, Asna U (2007) Antioxidant properties of various solvent extracts of mulberry (Morus indica L.) leaves. Food Chem, 102, 1233-1240

22. Bae KM, Park SH, Jung KH, Kim MJ, Hong SH, Song YO, Lee HS (2010) Effects of roasting conditions on physicochemical properties and sensory properties of Liripis tuber. J Korean Soc Food Sci Nutr, 39, 1503-1508

23. Lee GD, Yoon SR, Kim JO, Hur SS, Seo KI (2004) Monitoring on the tea with steaming and drying process of germinated buckwheat. J Korean Soc Food Sci Nutr, 32, 212-217.

24. Lee KS, Kim GH, Kim HH, Kim ES, Park HM, Oh MJ (2008) Quality characteristics of tea thermally processed from dried Lxeris dentata root. Korean J Food Preserv, 15, 524-531

25. Choi YH, Kim KH, Kang MY (2001) Varietal difference in processing and sensory characteristics of Sikhye in rice. Korean J Breed, 33, 65-72

26. Hong MJ, Lee GD, Kim HK, Kwon JH (1998) Change in functional and sensory properties of Chicory roots induced by roasting processes. Korean J Food Sci Technol, 30, 413-418

27. Kim HG, Kim GW, Oh H, Yoo SY, Kim YO, Oh MS (2011) Influence of roasting on the antioxidant activity of small black soybean (Glycine max L. Merrill). LWT-Food Sci Technol, 44, 992-998

28. Chio JS, Kim HY, Seo WT, Lee JH, Cho KM (2012) Roasting enhances antioxidant effect of bitter melon (Momordica charantia L.) increasing in flavan-3-ol and phenolic acid contents. Food Sci Biotechnol, 21, 19-26

29. Shin JH, Lee SJ, Seo JK, Cheon EW, Sung NJ (2008) Antioxidant activity of hot water extract from Yuza (Citrus junos Seib ex Tanaka) peel. Korean J Life Sci, $18,1745-1751$

30. Kwak EJ (2010) Development of brown colored rice tea with high GABA content. J Korean Soc Food Sci Nutr, 39, 1201-1205

(접수 2014년 7월 14일 수정 2014년 8월 25일 채택 2014년 8월 25일) 